\title{
New Design of Quarry Gravitricity
}

\section{Samir REMLI' ${ }^{1)}$, Djouama MOHAMED ${ }^{1)}$, Benselhoub AISSA ${ }^{1)}$, Rachid KHEBBAB ${ }^{1)}$, Nacereddine FELLOUH ${ }^{1)}$}

\author{
${ }^{1)}$ Laboratory of Mining Department, Badji Mokhtar University, Annaba, Algeria; email: benselhoub@yahoo.fr
}

http://doi.org/10.29227/IM-2020-01-08

Submission date: 04-01-2020 | Review date: 02-04-2020

\begin{abstract}
The consumption of electric energy in open pit mines or quarries maybe can achieve the consumption of all inhabitants of a city which it is according to their size and production of ore. in the other hand, View that the demand crescent of energy electric in the world, the limits of energetic resources in the third world, the increase of prizes operation and the maintenance of classic energy, the environmental consequences of classic energy and the benefic for using the autonomy system for production of electricity incites for searching the other sources responds the demands, To do this, we propose in this work a system equipped by generator for the creation of electrical energy resulting from the traffic of trucks in open pit mines whom situated in mountainous reliefs as knows a new kind of gravitricity.
\end{abstract}

Keywords: gravitricity, sustainable development, renewable energy, open pit mining design, quarry, truck

\section{Introduction}

Much of electrical energy used by humanity comes from fossil fuels. According to the international energy agency, its conventional resources represent $80.4 \%$ of global energy production, they are responsible for $40 \%$ of global emissions of $\mathrm{CO}_{2}$ [1]. In the context of sustainable development, in the face of the double global challenge posed by the risks of scarcity of fossil fuels and their effects on climate change, governments committed to the Kyoto Protocol must therefore multiply their actions in the energy production sector. in order to develop renewable, clean and inexhaustible sources of energy, the latter represent a considerable deposit at the global level [2].

The development and exploitation of renewable energies has grown strongly in recent years. From here and in the future, any sustainable energy system will be based on the rational use of traditional sources and increased use of renewable energies, for which purpose several research projects have been launched in several research laboratories in the field of sustainable development. , in order to satisfy the demand for energy consumption on the one hand and on the other hand to reduce the negative effects of fossil resources on the environment [3].

Ore deposits close to the surface are generally developed by open pit mining. Due to the hardness of the rock, mining is usually carried out by means of drilling and blasting. Large excavators load the material directly onto big trucks which convey the uncrushed rock from the mine. Most of the rock is overburden which is transported to one or several dumps close to the mine. On the other hand, the ore is driven to a crusher close to the processing plant. Apart from the simple way the uncrushed material is handled, this form of conveyance has the advantage of the trucks being able to be flexibly driven to the varying loading points and to be tipped at diverse points depending on actual requirements [4].

In the case where the quarry is situated in mountainous terrain, blasted rock is transported from benches in top to the crushing station at the bottom. Therefore, our work is to produce electricity from truck traffic in quarry. On the oth- er hand, to minimize the time of course of the trucks which will influx on the transport costs of blasted rock in quarry, by a proposal of a new installation contains rotating platforms which is loaded by truck fixed on the overall slope of quarry. this work is essentially, as the gravitricity system which is a huge 'clock weight'. A cylindrical weight of 500-5000 tones is suspended in a deep shaft by a number of cables each of which is engaged with a winch capable of lifting its share of the weight (fig.01). Electrical power is then absorbed or generated by raising or lowering the weight. This latest is guided by a system of tensioned guide wires (patents applied for) to prevent it from swinging and damaging the shaft. The winch system can be accurately controlled through the electrical drives to keep the weight stable in the hole [5].

\section{Theoretical study and prototype}

During the transportation of blasted rock within quarry which is in a mountainous terrain, the truck ascends empty and descends in charge. So the proposal is used to take advantage of electrical energy during the return of the loaded truck by installing a new system on which a generator plays a role of absorbing the braking power to get off the truck with a speed that ensures its descent safely. On the other hand, the distance of truck road will decrease which will influence of cost price of quarry. to do this, we made a prototype illustrates the disposition of new system of gravitricity in quarry (Figure 2).

After loading of truck by blasted rock thanks to a loader, it crosses along the bench until its end, then it embarks on the platform of new system of gravitricity after a fixation of that in bench thanks to the fastening devices, so using the truck's own weight, the blade of the system rotates until arrival of truck at the lower bench which will continue its way to crushing station or the place of storage. So this blade movement generates a rotation of the generator through a speed multiplier to produce energy that will then store in storage batteries and dedicated either to the companion itself or to the power grid to feed the city. The edges of benches next to the system 


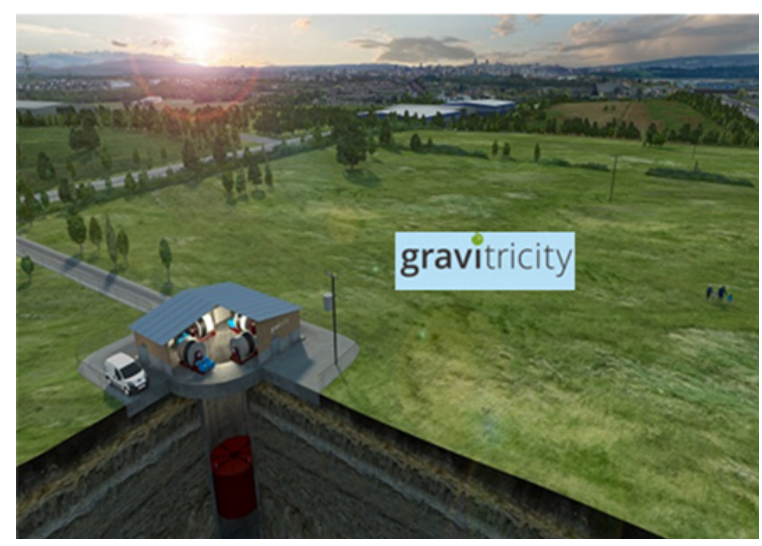

Fig.1. Gravitricity in shaft mine

Rys. 1. Odzysk energii w szybie kopalni

are built according to the rotation of blade, so all of them form an arc. The batteries of energy storage is put in order to avoid the cut of electricity in the case where the blade stops for the embarkation or the descent of the truck from platform of system. Also an electricity regulation inverter is installed before dedicating electrical energy to the users.

For best understanding of this new kind of gravitricity system, we can take an example for more explanation.

We have the gravity $g=9.81 \mathrm{~m} / \mathrm{s}^{2}$.

We have the mass of loaded truck $\mathrm{m}=60000 \mathrm{Kg}$, with a high $\mathrm{H}=30 \mathrm{~m}$.

So, for calculation of power created from generator, we must in begin calculate the power generated from free fall of mass. This latest is lowering to inferior bench in open pit mining; its free fall will take a time as follow:

$\mathrm{t}=\sqrt{ }(\mathrm{H} / \mathrm{g} \cos \beta)=\sqrt{ }(30 / 9.81 \cos 50)=2.18 \mathrm{~s}$.

$\beta=$ it is the inclination of moving of platform loaded by truck with a certain angle (fig.03); ${ }^{\circ}$

we have the law of power $P$ :

$\mathrm{P}=\mathrm{c}^{*} \omega, \mathrm{Kw}$.

c: torque; $\mathrm{Nm}$.

$c=F^{*} \cos \beta^{*} \mathrm{~L}=60000 * 9.81 * \cos 50 * 30=11301120 \mathrm{Nm}$

$\omega$ : angular speed $\mathrm{rad} / \mathrm{sec}$

$\omega=\mathrm{v} / \mathrm{L} ; \mathrm{rad} / \mathrm{sec}$

So the speed of mass in free fall $\mathrm{v}$ is:

$\mathrm{v}=\mathrm{H} / \mathrm{t}=30 / 2.18=13.76 \mathrm{~m} / \mathrm{s}$.

$\omega=13.76 / 30=0.45 \mathrm{rad} / \mathrm{sec}$

The best speed of platform loaded by truck when it is lowering is $\mathrm{v}=0.4 \mathrm{~m} / \mathrm{s}$. this latest is according to cadence of mine production (time of cycle of trucks to carry out the planned production)

\section{L: length of blade (fig.04) $\mathrm{L}=30 \mathrm{~m}$.}

Now we can calculate the total power as follows:

$\mathrm{Pt}=11301120^{\star} 0.45^{*}(1-0.3)=3559852,8 \mathrm{w}=3559.85 \mathrm{Kw}$

We can consider the ratio of friction of generator and multiplier wearing of resistance is assimilated for 30 percent from total power (according to system of hydraulic energy). Therefore, the value (1-0.3) represents the yield of system.

If we want to minimize this linear speed from $13.76 \mathrm{~m} / \mathrm{s}$ to $0.4 \mathrm{~m} / \mathrm{s}$, we must slow down the free fall with a retarding force, for doing this, it is necessary to put multiplier as shown in fig.02, which is records also with a generator. The forces of resistance of this generator equal a retarding force which let the speed minimize to $0.4 \mathrm{~m} / \mathrm{s}$.

Than; the lost power PL in the movement of mass when the speed $\mathrm{v}=0.4 \mathrm{~m} / \mathrm{s}$ is as follows.

$\mathrm{t}=\mathrm{H} / \mathrm{v}=30 / 0.4=75 \mathrm{~s}$,

So; the acceleration is:

$\mathrm{a}=30 /(75) 2=0.0053 \mathrm{~m} / \mathrm{s}^{2}$

The angular speed: $\omega=\mathrm{v} / \mathrm{r}=0.4 / 30=0.013 \mathrm{rad} / \mathrm{sec}$

$c=F^{*} \cos \beta^{\star} L=60000 * 0.0053 * \cos 50 * 30=6105,6 \mathrm{Nm}$

$\mathrm{PL}=6105,6^{\star} 0.013=79.37 \mathrm{w}=0.0079 \mathrm{Kw}$.

The subtraction of this two powers given the power energy generated Pg from the generator whom represents the retarding power which cited above.

$\mathrm{Pg}=\mathrm{PL}-\mathrm{Pt}=3559.85-0.0079=3559,84 \mathrm{Kw}$.

Electric energy generated from a generator during one hour: If we analyze the electricity production of the generator, we should put into consideration all times of movement of trucks, so we have:

- Time of riding of truck into platform. $\mathrm{Tr}$

- Time of lowering of truck. Tl

- Time of descend of truck. Td

In all of these times cited above, we find only the time of lowering of truck whom can product energy from its moving. but other timeout the system is stopping and there is no energy created. So from the example taken above we can calculate the energy created from the generator in one hour.

In general, in the mine, the trucks take 10 seconds to ride or descent from the balance to measure their weights.

So $\operatorname{Tro}=\mathrm{Tr}+\mathrm{Tl}+\mathrm{Tr}=10+75+10=95$ second.

Tro time of energy product.

The timeout $\mathrm{To}=\mathrm{Tr}+\mathrm{Td}=5+5=10$ second

In one hour the movement of system is 154 rotations ( 3600 / $23.33=154.3$ )

To know the timeout in one hour Toh $=154^{\star} 10=1540$ second 


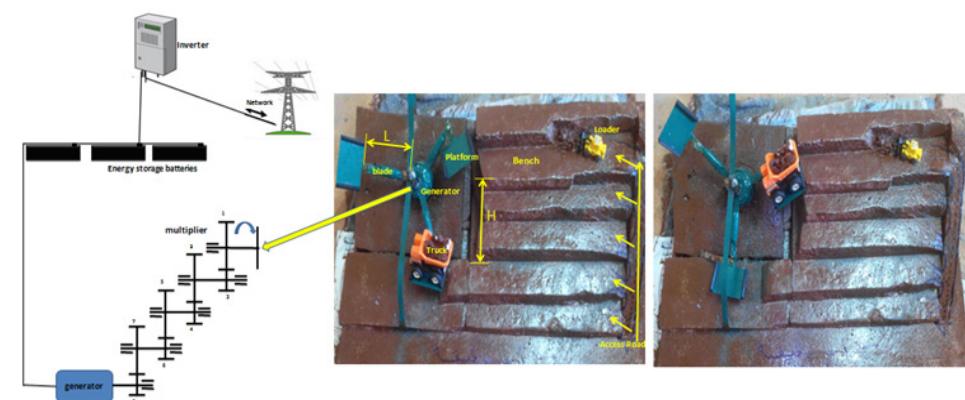

Fig. 2. New system of gravitricity Rys. 2. Nowy system odzysku energii

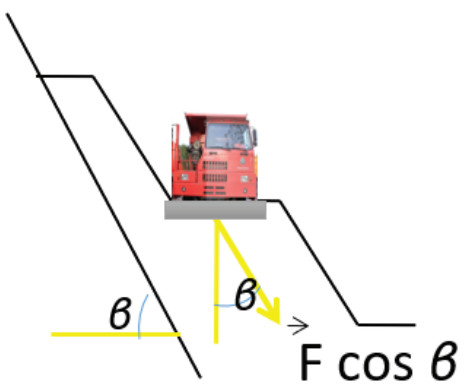

Fig. 3. Angle of inclination of platform moving loaded by truck Rys. 3. Kąt nachylenia platformy poruszającej się z ładunkiem ciężarówki

So the time of energy product is $154^{\star} 13.33=2052.82$ second. We have the power of generator installed is $3559,77 \mathrm{Kw}$ but it work 2052.82 second in one hour, so the generator can product $2029 \mathrm{Kw} / \mathrm{h}((2052.82 * 3559,77 / 3600)=2029 \mathrm{Kw} / \mathrm{h})$.

The electric energy created by the generator connects to the batteries for stock it to provide the continuous of this energy for users without interruption and to transform it from the direct to alternating current, we must use inverters corresponding the power of energy created.

As the stady of SIEMAG TECBERG, the advantage lies in the transport time being curtailed by the difference in height being rapidly overcome. While the trucks move upwards at less than $3 \mathrm{~m} / \mathrm{s}$ on a slope of $10 \%$ at the maximum, a slope hoisting plant can overcome the mine's natural angle of repose of over even $50^{\circ}$ at $8 \mathrm{~m} / \mathrm{s}$. This means that a truck is hoisted to surface in only 2 minutes while driving on the haul road incline takes some 20 minutes (from $300 \mathrm{~m}$ depth, time for driving on and off the TruckLift platform included). Whereas one vehicle is on the slope with the TruckLift plant at one time, conventional haulage requires a large number of trucks only on the inclined part of the road for achieving the same transport volume. Thus, the truck fleet can correspondingly be reduced. Comparing the costs by the present value method using an interest rate of $10 \%$ on future costs and considering an annual price increase of $3 \%$, investing in a slope hoisting plant usually pays off within less than five years. During a plant's running time of 20 years, a volume of up to $60 \%$ can be saved with regard to gradient transport (fig.05).

\section{Conclusions}

The study requires more details on the performance of this new kind of gravitricity to know its feasibility. Therefore, several factors influence the realization of this system such as: the shape of the deposit, the method of exploitation, the mode of opening. On the other hand, there is a chain of correspondence of many trucks and their capacities of dumps, also the planned production and all that to avoid the cut of blade rotation which will influence on the production of electrical energy. 


\section{Literatura - References}

1. Buzdugan, M. Lopez, “Contribution à l'Optimisation d'un Système de Conversion Eolien Pour une Unité de Production Isolée ”, Thèse de Doctorat, Université de Paris-Sud, 2008.

2. R.Chedid and S.Rahman, "Unit Sizing and Control of Hybrid Wind-Solar Power Systems", IEEE

3. Transactions on Energy Conversion, Vol. 12, No. 1, March 1997.

4. M. Muralikrishnan and V. Lakshminarayana, "Hybrid (Solar and Wind) Energy System for Rural Electrification ”, ARPN Journal of Engineering and Applied Sciences, Vol. 3, No. 5, October 2008.

5. SIEMAG TECBERG, Technical Information, TruckLift System (Innovative Transport Technology for Open Pit Mines).

6. www.gravitricity.com

\section{Nowe spojrzenie na odzysk energii w kopalni odkrywkowej}

Zużycie energii elektrycznej $w$ kopalniach odkrywkowych lub kamieniołomach może osiagnąć poziom zużycia energii w mieście, zużycie energii w kopalni zależy od rodzaju kopaliny $i$ wielkości wydobycia. Przedstawiono zmiany popytu na energię elektryczna na świecie, ograniczenia zasobów energetycznych $w$ Trzecim Świecie, proporcje udziału energii konwencjonalnej, konsekwencje środowiskowe wykorzystania energii oraz korzyści z wykorzystania z systemu autonomicznego produkcji energii elektrycznej. Wszystko to zachęca do poszukiwania alternatywnych źródeł energii. Autorzy zaproponowali w pracy system wyposażony w generator energii elektrycznej bazujący na odzysku energii z przemieszczania się ciężarówek w kopalniach odkrywkowych.

Słowa kluczowe: odzysk energii, zrównoważony rozwój, energia odnawialna, projektowanie kopalni odkrywkowych, kamieniołom, ciężarówka 